\title{
Continuidade Hegel-Marx? Solução especulativa em Burocracia e Ideologia para a relação entre Estado e sociedade no modo de produção asiático
}

\author{
Hegel-Marx continuity? Speculative solution in Bureaucracy and Ideology to the \\ relationship between State and society in the Asiatic mode of production
}

Elcemir Paço Cunha ${ }^{1}$

Universidade Federal de Juiz de Fora, Faculdade de Administração, Juiz de Fora - MG, Brasil

\begin{abstract}
Resumo
Discussão sobre o argumento de Tragtenberg, em Burocracia e ideologia, segundo o qual o Estado gera a sociedade no modo de produção asiático, o que requereria um regresso de Marx a Hegel ou o aceite de uma continuidade HegelMarx. Por meio desta discussão aponta-se que Tragtenberg chega ao aceite do aforismo hegeliano segundo o qual o Estado (e sua burocracia) é o demiurgo da sociedade em virtude do problemático amálgama entre Marx e Hegel, a despeito das inúmeras problemáticas decorrentes.
\end{abstract}

Palavra-chave: Tragtenberg. Hegel. Marx. Estado. Sociedade. Modo de produção asiático.

\begin{abstract}
This paper aims at to discuss the Tragtenberg's argument founded in Bureaucracy and ideology according to which the State generates society at the Asiatic mode of production. This argument demands, according to Tragtenberg, a return from Marx to Hegel and an acceptance of Hegel-Marx continuity. Our discussion shows that Tragtenberg take as valid the Hegelian aphorism, which determines the State (and its bureaucracy) as the demiurge of society as consequence of a problematic amalgam between Marx and Hegel, notwithstanding the many inconsistencies that rise from it.
\end{abstract}

Keywords: Tragtenberg. Hegel. Marx. State. Society. Asiatic mode of production.

\section{Introdução}

A tradição crítica do pensamento social brasileiro é certamente muita rica. Entre os autores e discussões, Tragtenberg ocupa um lugar distintivo por sua heterodoxia diante daquilo que ele considerava como a ortodoxia oficial (Lenin, Trotsky, Stalin). Tratou essa "ideologia" com profunda razão crítica ao considera-la como expressão legitimadora da opressora burocracia por meio da qual se manteve a dominação de um capitalismo de Estado na antiga União Soviética, algo distante da necessária auto-organização do

Artigo recebido em 25 de fevereiro de 2014 e aceito para publicação em 20 de agosto de 2014.

DOI: http://dx.doi.org/10.1590/1679-395116965

Agradecimentos à FAPEMIG (Fundação de Amparo à Pesquisa do Estado de Minas Gerais) pelo auxílio financeiro à pesquisa que permitiu a elaboração do presente artigo.

${ }^{1}$ Doutor em administração pela Universidade Federal de Minas Gerais; Professor adjunto da Universidade Federal de Juiz de Fora. Endereço: UFJF, Rua José Lourenço Kelmer, s/n - Campus Universitário, São Pedro, CEP 36036-900, Juiz de Fora - MG, Brasil. Email: paco.cunha@ufjf.edu.br 
trabalhador. Mas a distinção do autor brasileiro igualmente se marca pelas críticas contumazes à "teoria" da administração enquanto ideologia, numa década (particularmente 1974) em que a administração se desenvolvia a passos largos em um Brasil sob regime militar.

Paes de Paula, Maranhão, Barreto et al. (2010) têm razão ao indicar que a tradição crítica brasileira antecede em décadas as expressões mais sistematizadas de uma relativa crítica à administração, conforme ficou estabelecida na década de 1990 a "corrente" denominada frequentemente por "estudos críticos da gestão" que, mesmo por ser "crítica", não deixa de ser uma elaboração do ponto de vista do capital. Antecede e com particularidades, uma vez que mantém uma autonomia teórica fundada em outros matizes intelectuais. É o caso de Tragtenberg, que sustentava influências das mais diversas, incluindo sobretudo Hegel, Marx, Weber, além da análise cunhada nas bases aguerridas de um anarquismo, deixando marcas indeléveis na formação de inúmeros intelectuais brasileiros.

Tragtenberg, por esses e outros motivos, recebeu e recebe considerável atenção de pesquisadores no Brasil. À guisa de exemplo, além de compilações dos seus artigos em livros (Autonomia operária; A falência da política; Educação e burocracia; Teoria e ação libertária), o autor brasileiro é tema de livros organizados desde o início da década de 2000 (cf. ACCIOLY, SILVA e MARRACH, 2001; VALVERDE, 2011), de artigos publicados em importantes periódicos (BRUNO, ACCIOLY e SILVA, 2011; MENEGHETTI e FARIA, 2011; PAÇO-CUNHA, 2013; PAES DE PAULA, 2002; 2008; cf. edição especial da Revista Espaço Acadêmico, v. 13, n. 150, 2013), de teses e dissertações (MENEGHETTI, 2009; SILVA, 2004), além de eventos dedicados ao debate de sua obra e à sua memória, congregando pesquisadores e estudiosos das diferentes áreas das ciências sociais e humanas. Trata-se de uma elaboração teórica em torno do projeto de emancipação sempre presente na obra do autor brasileiro, para muito além das meras reformas e alegadas humanizações tanto do Estado quanto das demais esferas sociais, constituindo-se, pois, numa autêntica crítica para além do capital, quando posto lado a lado com os tais "estudos críticos da gestão".

Mediante uma produção que já acumula muitas páginas, discussões, críticas e elogios, restringimo-nos aqui ao material que é considerado por muitos a obra de maior fôlego de Tragtenberg (e.g. ANTUNES, 2001), Burocracia e ideologia (TRAGTENBERG, 1974). Estamos ocupados sobretudo com a discussão que corta seu primeiro capítulo, no qual desenvolve a argumentação necessária à determinação da burocracia como classe dominante no modo de produção asiático. Trata-se de um capítulo escrito sob condições especiais e que repercutiu polemicamente como parte componente da tese de doutoramento do autor brasileiro (cf. TRAGTENBERG, 1999, p. 69)

Para Tragtenberg, como veremos, fica demonstrado o argumento de um inevitável regresso de Marx a Hegel, ou melhor, uma continuidade Hegel-Marx, uma vez que neste modo de produção asiático (como abordado pelo autor brasileiro) é o Estado que gera a sociedade. Isso implicaria uma inversão da determinação ontológica dessa relação, conforme Marx $(1974 ; 2005)$, e inúmeros outros problemas ligados à exagerada aproximação entre os autores alemães. Uma determinação marxiana desse tipo não quer dizer outra coisa senão uma relação de anterioridade histórica efetiva, um nexo real de pressuposição que no presente caso retrata a determinação entre Estado e sociedade. E aqui estaria uma das marcas distintivas entre o materialismo marxiano iniciado em 1843 e o idealismo hegeliano. Hegel, como ainda veremos, determinava o Estado (ou a Ideia de Estado) como anterioridade à sociedade. Ao contrário, Marx apreendia o movimento contraditório da sociedade como pressuposto primário da existência do Estado. Este ângulo permite a compreensão de um pensamento propriamente marxiano dado por superação da filosofia especulativa de Hegel.

A questão central, portanto, que move o presente estudo pode ser assim situada: por que Tragtenberg, por via especulativa, determina que o Estado gera a sociedade no modo de produção asiático se o seu fundamento "metodológico" está, em parte, no próprio Marx e se o material deste, consultado pelo autor brasileiro, fornece provas do contrário? Os motivos, como veremos, estão relacionados aos operatórios empregados pelo próprio autor brasileiro a despeito das inúmeras problemáticas inerentes. 
Algumas ressalvas são necessárias. Primeiramente, as discussões e polêmicas sobre o modo de produção asiático são muitas e com significados variados (cf. BANAJI, 2010; DUNN, 2011; GODELIER, 1972; SAWER, 1977; SHANIN, 1983; WITTFOGEL, 1963), rendendo avanços, mas também animosidades políticas e acusações de eurocentrismo e preconceito. Embora não seja possível nem útil retomar aqui essa longa discussão, é preciso deixar claro que não se trata de uma delimitação geográfica (pelo termo "asiático"), nem de uma hierarquização justificadora das formas de imperialismo. O modo de produção asiático marxianamente determinado, como veremos, é uma categoria que expressa um modo de produção particular, quer dizer, um modo de articulação, no interior de uma unidade, entre sociabilidade e individualidade comparativamente a essa articulação na forma do capitalismo. Para Marx, portanto, o modo de produção em questão, assim como os demais modos pré-capitalistas, servem mais à explicitação da diferença específica do modo de produção capitalista do que se confirmam como objetos autonomizados de uma historiografia dedicada à caracterização exaustiva.

Em segundo lugar, e desconsiderando as más compreensões movidas pelo irracionalismo e suas expressões mais e menos difundidas (como versões do multiculturalismo que identificam em Marx um etnocentrismo), muito da retomada da discussão sobre o modo de produção asiático ao longo do século XX deve-se sobretudo à suposta proximidade, em termos de forma, que explicaria a antiga União Soviética, e à publicação dos famosos Grundrisse (MARX, 2011a), nos quais aparecem inúmeras considerações acerca dos modos de produção pré-capitalistas. Porque havia uma presença do Estado burocrático centralizado na União Soviética, aplicou-se a terminologia para indicar que não houve uma instauração do socialismo, mas a restauração do antigo sistema asiático de governo centralizado (cf. TREADGOLD, 1987, p. 8). Retiveram-se as semelhanças para essa aplicação da terminologia, desconsiderando parcialmente o fato, que fornece uma das diferenças fundamentais, de a revolução russa ter reciprocidades com o capitalismo já desenvolvido, além de outros traços não comuns. Tragtenberg (1974, p. 56; 187-9; 2009a, p. 332) mantinha alguma inclinação para esta última consideração na qual se avalia a União Soviética por proximidade com o modo de produção asiático e estava particularmente interessado em acompanhar o perfilar da burocracia na história. Desse modo, a atenção do autor brasileiro recai mais sobre a burocracia do que sobre o modo de produção asiático, ou melhor, este serve à explicitação histórica daquela - e não é demais lembrar que Tragtenberg escreve no início da década de 1970, em plena ditadura militar e com forte interferência burocrático-governamental na economia brasileira. Entretanto, não é possível negar que o modo de produção asiático seja o elemento que permite a Tragtenberg chegar à suposta validade do aforismo hegeliano segundo o qual o Estado gera a sociedade. Em outras palavras, é o modo de produção asiático que permite o operatório Hegel-Marx no desenvolvimento de Burocracia e ideologia. Por isso, nossa atenção deve recair sobre tal modo de produção em pauta se quisermos explicitar a questão central estabelecida, isto é, indicar elementos explicativos dos motivos que levaram Tragtenberg a uma solução especulativa, fixando o Estado como anterioridade à sociedade naquele modo de produção particular.

Por último, nossa preocupação, portanto, não deve abarcar um levantamento histórico das condições sob as quais Tragtenberg escreveu o texto em questão nem as suas demais considerações que também tangenciam o problema em tela (e.g. TRAGTENBERG, 1967; 1986; 1988). Não abarca igualmente uma discussão dedicada inteiramente aos problemas ligados ao modo de produção asiático, tampouco busca detalhar as polêmicas em torno da burocracia. A problemática do modo de produção nos é importante neste momento apenas na medida em que Tragtenberg lida com o pensamento de Marx, resgatando variadas considerações deste autor alemão em ligação com Hegel (e Weber). O pensamento de Tragtenberg, particularmente acerca dos problemas do modo de produção asiático (e também da burocracia), fica inteiramente incompreendido sem a apreensão do resgate e dos nexos que o autor brasileiro, certo ou errado, estabelece entre esses autores alemães, particularmente Marx e Hegel. No entanto, uma consideração aprofundada dessa ligação (a não ser com Hegel) e a problemática mais direta sobre a burocracia terão que ficar para uma oportunidade dedicada, aparecendo aqui apenas de forma secundária (em algumas parcas passagens e notas) quando, para o caso da burocracia, não houve possibilidade de contornar a argumentação do próprio Tragtenberg que liga diretamente burocracia (enquanto Estado) e modo de produção asiático. Da mesma forma, uma discussão sobre o problema da Rússia pré-revolucionária e a possibilidade do modo de produção asiático como categoria explicativa deste e do momento histórico seguinte terá que aguardar momento oportuno por 
retomar uma série de textos do próprio Marx em certo diálogo com os chamados "populistas russos", os quais criariam dificuldades para além da problemática aqui em pauta - textos os quais, inclusive, a categoria modo de produção asiático tende a não ser empregada em favor de "comunidade agrícola" (cf. FERNANDES, 1982; KRADER, 1974; MARX e ENGELS, 2013).

Feitas as devidas ressalvas, importa-nos mais de perto a apreensão de Tragtenberg sobre as considerações marxianas a respeito da relação entre Estado e sociedade no modo de produção asiático, particularmente no importante primeiro capítulo de Burocracia e ideologia, em que se estabelece a continuidade Hegel-Marx. Com efeito, o próximo tópico dará conta de mostrar a argumentação de Tragtenberg que estabelece o regresso de Marx a Hegel, dando margem para dois aspectos de um mesmo problema: 1. a cisão entre Estado e sociedade no modo de produção asiático e 2. a defesa por parte do autor brasileiro do aforismo hegeliano do Estado como aquilo que gera a sociedade. Em seguida, apresentamos as colocações mais centrais de Marx para explicitar a problemática recuperação que Tragtenberg opera ao aceitar o aforismo hegeliano, embora o próprio Marx também seja um dos seus pontos de partida metodológicos, por assim dizer. E, já na forma de considerações finais, traçamos uma discussão do presente artigo.

\section{O Regresso de Marx a Hegel e a Solução Especulativa Tragtenbergiana}

Qualquer discussão sobre o problema aqui em tela seria vazia sem as provas que dessem conta de indicar a argumentação de Tragtenberg. Uma retomada da letra, nesse sentido, é fundamental e metodologicamente justificável, evitando imputar ao autor elementos ausentes ou mesmo estranhos ao quadro geral da estrutura argumentativa. Seguindo Chasin $(2009$, p. 25), é preciso "[...] reproduzir pelo interior mesmo da reflexão [...] o traçado determinativo [dos] [...] escritos, ao modo como o próprio autor os concebeu e expressou", de modo que "[...] antes de interpretar ou criticar é incontornavelmente necessário compreender e fazer prova de haver compreendido". Levamos esse operatório, portanto, ao autor brasileiro por necessidade de um pensamento de rigor que aqui buscamos desenvolver.

Como já ressalvamos, a matéria do livro em termos gerais não se resume ao problema do modo de produção asiático. Para além disso, Tragtenberg $(1974$, p. 15) busca "[...] examinar o surgimento e o perecimento das teorias administrativas através do tempo, conforme as determinações econômico-sociais existentes". Está, pois, ancorado "[...] em perspectiva estritamente sociológica, no nível de sociologia do conhecimento" (TRAGTENBERG, 1974, p. 16), a qual mais tarde descobrimos centra-se em Mannheim (TRAGTENBERG, 1974, p. 44, nota de rodapé 71). Porém, seu ponto de partida mais aproximado de uma posição "metodológica" pode ser explicitado na distinção entre "níveis" para uma "análise categórica baseada em textos" (1974, p. 16). Lemos, assim, que:

Em nível lógico, como administração significa burocracia, aproveitamos a contribuição de Hegel a respeito; em nível histórico, na medida em que as teorias administrativas são transitórias (ideológicas), porque refletem interesses económico-sociais transitórios, fundamo-nos na perspectiva dialética; e, em nível lógico-histórico, na medida em que as teorias administrativas posteriores, embora refletindo momento histórico-econômico diverso do anterior, trazem em seu âmago o conhecimento cumulativo das teorias preexistentes, fundamo-nos na perspectiva de Marx, da relativa autonomia da produção teórica em relação às determinações econômico-sociais globais. (TRAGTENBERG, 1974, p. 16, grifos no original).

Nessa conjunção metodológica, por assim dizer, aparecem três níveis nos quais, de alguma forma, amalgamam-se Hegel e Marx logo de partida. Embora não encontremos maior desenvolvimento sobre este aspecto no transcorrer do livro, parece que em Marx se sintetizariam os dois "níveis", isto é, o "lógico" e o "histórico", mas submetidos ao operatório de uma "interpretação e associação nova de ideias" 
(TRAGTENBERG, 1974, p. 17, grifos no original), como podemos ler logo em seguida à passagem imediatamente anterior, que dá conta dos "níveis".

Esse aspecto por si só já contém a problemática de uma reflexão dedicada, uma vez que toda a discussão envolvendo uma transitividade entre Marx e Hegel também já acumula rios de páginas, além das polêmicas e confusões engendradas por operatórios mais ou menos permissivos (o jovem Lukács que o diga). Porém, deixando isso para ser retomado mais adiante, no próximo tópico, fiquemos por agora apenas com o registro de uma ausência mais específica sobre tais "níveis", com o pouco desenvolvimento desse aspecto metodológico, e também com o registro dessa aproximação demasiada entre Hegel e Marx. Fica demarcado que Tragtenberg tem, além de Hegel ao "nível lógico", a "perspectiva de Marx" como ponto de partida, mas apenas como resultado da conjunção.

E por que Tragtenberg desenvolve o primeiro capítulo sobre o modo de produção asiático? Para indicar a constituição da burocracia patrimonial nessa forma passada pré-capitalista, constituição como anterioridade histórica da burocracia moderna na empresa e no Estado, uma vez que, suportado por Hegel, o autor brasileiro estabelece que "administração significa burocracia" (TRAGTENBERG, 1974, p. 16). Embora, como dito antes, nossa preocupação não possa recair exclusivamente sobre esta categoria, a burocracia no modo de produção asiático é desenvolvida por Tragtenberg sobretudo com base em Hegel porque nele se encontrariam "[...] as determinações conceituais que permitem a análise da burocracia do Estado, da burocracia enquanto poder político que antecede em séculos a emergência da burocracia determinada pelas condições técnicas da empresa capitalista, oriunda da Revolução Industrial" (TRAGTENBERG, 1974, p. 28 , grifos no original).

Destaca-se nesse desenvolvimento não apenas tal ponto de partida, mas também a amplitude da leitura de Tragtenberg sobre o tema em questão, recuperando não apenas elementos de Marx e de Weber, mas também de autores como Engels, Lenin, Wittfogel, Chesneaux, e autores destoantes como Von Mises, além de muitos outros mais regredidos no tempo, como Aristóteles e Maquiavel. Nosso autor, portanto, coleciona uma gama de elementos descritivos do modo de produção asiático e procura situar a burocracia como poder político de tipo específico, isto é, como classe dominante. Assim, podemos ler que:

A burocracia, enquanto classe dominante (detentora dos meios de produção), elemento de mediação com a sociedade global, exercendo o poder político, perfila-os [provavelmente se referindo aos estamentos tratados em seu parágrafo anterior] ante a História como uma forma de dominação burocrático-patrimonial ou modo de produção asiático. No modo de produção asiático, o déspota oriental representa a confluência de um processo social, que se inicia com a burocracia, surgindo das necessidades técnicas (irrigação da terra arável), finalizando como poder de exploração, efetuando-se assim a transitividade da burocracia cumprindo funções de organização e supervisão para o monopólio do poder político. (TRAGTENBERG, 1974, p. 25, grifos no original).

Ao final dessa passagem temos a citação de $O$ Capital em nota de rodapé, particularmente extraída do capítulo sobre a cooperação ${ }^{2}$. Tudo indica que Tragtenberg via na passagem da obra magna marxiana a

\footnotetext{
2 "'Os efeitos da cooperação simples no modo de produção asiático aparecem em seu aspecto colossal nas gigantescas obras dos antigos asiáticos, egípcios e etruscos. $\mathrm{Na}$ antiguidade, tais Estados asiáticos, depois de empregarem a maioria de seus recursos na área civil e militar, possuíam um excedente de produtos para converter em obras de ornamento e utilidade. O domínio que possuíam o rei e os sacerdotes, sobre mão-de-obra de tal população não ocupada na agricultura e o poder exclusivo para dispor de tal excedente, oferecia-Ihes os meios para levantar aqueles ingentes monumentos que cobriam o país. Utilizou-se quase exclusivamente a força humana para construção e transporte daquelas estátuas colossais e daquelas enormes massas, cuja possibilidade de terem sido transportadas, ainda hoje nos assombra. Para tanto, bastou concentrar uma multidão de trabalhadores e unificar seu esforço' (Marx, K. 'Le Capital'. In: Oeuvers. Paris, Ed. De La Pleiade, 1965, p. 873)”. (TRAGTENBERG, 1974, p. 25, nota 15). Tragtenberg reproduz, no entanto, de modo inadequado essa passagem, pois a única coisa que pertence a Marx mesmo é a
} 
sustentação necessária ao argumento de que, para Marx, a burocracia constitui em si uma classe dominante no modo de produção asiático. Se tivermos em mente, como Tragtenberg (1974, p. 23-24) tinha também bastante claro, que a burocracia do ponto de vista hegeliano (e nele se trata de um produto moderno, não algo comum a todas as épocas) era tomada como "classe universal" (cf. HEGEL, 2010, §205, p. 201), explica-se a determinação do autor brasileiro de apreendê-la como classe dominante - algo que, não obstante as profundas distinções, também podemos encontrar em Weber quando escreve, por exemplo, que o decisivo é "quem é que domina o aparelho burocrático existente" (WEBER, 2009, p. 146, grifo no original). Não é de todo impossível assumir a possibilidade de que esse direcionamento seja resultante de uma convergência traçada por Tragtenberg entre Hegel e Weber pelo fato de ambos (cada um ao seu modo) terem tratado da burocracia moderna. Wolkmer (2003) teve impressão semelhante, porque capturou a retenção de Hegel nessa questão. Ainda que de modo não muito preciso ao retirar os meios de produção da argumentação de Tragtenberg, escreveu Wolkmer que "[...] em Burocracia e ideologia, Maurício Tragtenberg parte das premissas hegelianas, tentando identificar a noção de burocracia com a administração estatal". E completou: "A análise tragtenbergiana se atém à premissa de que Hegel desenvolve a teoria da burocracia na medida em que esta se configura como classe que governa" (WOLKMER, 2003, p. 47).

As considerações de Tragtenberg sugerem ter mais afinidade com Hegel ou Weber (ressalvados os pontos problemáticos e de distinção entre eles) do que com o próprio Marx. E isso é tanto mais verdade não apenas pela dificuldade em determinar por meio de Marx a burocracia como classe dominante ${ }^{3}$, como, também por meio dele, delimitar a existência de uma autêntica burocracia no modo de produção asiático ${ }^{4}$. Ainda assim, se considerarmos que a burocracia como classe universal em Hegel diz respeito ao moderno Estado e não ao mundo antigo (como ainda veremos), podemos precisar que Tragtenberg ou imputa por meio de Hegel algo do moderno ao passado ou é influenciado indiretamente por Weber e suas bem conhecidas digressões sobre as formas de dominação, particularmente pelas descrições das burocracias chinesa e egípcia - e não se deve desprezar as nada ausentes influências de Weber no pensamento do autor brasileiro. Ou ainda, é possível considerar uma influência de ambos à medida em que supostamente convergem porque estudaram a burocracia.

Hegel, Marx e Weber surgem assim amalgamados por motivos diferentes. Por um lado, por Tragtenberg tomar a categoria da dominação como algo que une os dois últimos e, por outro, por considerar uma plena transitividade entre os dois primeiros. Embora não seja possível tratar aqui da primeira parte desse

primeira frase (de "Os efeitos da cooperação simples [...]" até "[...] asiáticos, egípcios e etruscos"), sendo o restante advindo da citação de R. Jones reproduzida por Marx (cf. MARX, 1962, p. 353; 2013, p. 409). Não tivemos acesso à edição usada por Tragtenberg para determinar melhor as causas do problema.

${ }^{3}$ Veja a discussão de Antunes (2003) quando procura argumentar que, diferentemente de Engels, na maneira como Marx tratava a questão, se insinua a não existência de classes no modo de produção asiático, o que ajudaria a explicar seu caráter mais ou menos estacionário. $\mathrm{O}$ assunto é polêmico e precisamente isso evidencia a necessidade de uma investigação dedicada ao assunto em vez de imputar o caráter de classe à "burocracia", nos termos de Tragtenberg. Tal feito só pode ser realizado por interferências hegelianas e/ou weberianas.

${ }^{4}$ Como adiantado na introdução, este é outro assunto profundamente problemático e que merece um texto dedicado. Não será possível tratar detidamente deste aspecto, mas existem indicações de que, marxianamente pensada, a burocracia é uma categoria que expressa o formalismo do Estado moderno, que surgiu, no entanto, das entranhas das monarquias absolutistas (cf. MARX, 2011b; 2011c). Isto não significa a inexistência de uma divisão social do trabalho no modo de produção asiático de maneira que uma parte da sociedade ligada ao governo central exerça o "trabalho de supervisão e ingerência" sobre a massa do povo. Uma tal divisão social do trabalho e a progressiva cristalização de determinadas funções na dimensão do governo central não seriam suficientes para determinar um formalismo de Estado que teria condições econômicas e sociais bastante específicas. Aqui, como em muitos outros lugares, estamos diante do problema marxiano de revelar as coisas efetivamente existentes por meio das categorias correspondentes e também de existência real em lugar de imputar à realidade conceitos gerais porque empiricamente - aqui no sentido restrito - faria algum sentido, por exemplo, determinar o governo central indiano como burocracia, em tempos remotos, pelo simples valor heurístico do conceito. Poder-se-ia talvez falar com muitas mediações de uma "protoburocracia" nessas formações políticas do passado, mas um estudo dedicado é requerido. 
argumento (dominação), veremos que esse segundo amálgama (Hegel-Marx) cumpre função especial na elaboração do autor brasileiro.

Com efeito, quando o assunto era precisar diretamente (e não indiretamente por meio de notas complementares) o modo de produção asiático em Marx, Tragtenberg parte da afirmação de que Hegel "[...] influenciou Marx no conceito das sociedades hidráulicas como estacionárias, sem história porque não mudam, e sua fragmentação do poder, como na Índia, torna-as presa fácil de conquistadores" (TRAGTENBERG, 1974, p. 50). Por um lado, destaque-se esta ambiguidade analítica de considerar que o modo de produção asiático possui uma "fragmentação do poder" em contraste com a passagem destacada anteriormente (cf. TRAGTENBERG, 1974, p. 25) na qual sugere, ao contrário, como possuindo poder centralizado. Por outro lado, vemos o que se repete com bastante frequência: considerar uma transitividade plena entre Hegel e Marx.

Além de assentar a elaboração de Marx em Hegel - o que é questionável no que tange a este aspecto sem elementos que proporcionassem as provas necessárias -, Tragtenberg parece guardar dúvidas sobre o tratamento dado pelo primeiro, uma vez que "[...] os textos de Marx a respeito não constituem uma construção elaborada, como a que fizera a respeito do capitalismo. O modo de produção asiático para Marx, significa, antes de mais nada, a análise da China e Índia, na situação em que foram encontradas pelo capitalismo industrial europeu do século XVIII" (TRAGTENBERG, 1974, p. 50). Isso está em claro contraste com o ponto de partida do capítulo em questão quando escreveu que "o modo de produção asiático fora enunciado inicialmente por John Stuart Mill em 1848 e Montesquieu no seu De l'espirit des lois, posteriormente desenvolvido, sistematicamente por Marx, K. em El capital, v. único, cap. XI" (TRAGTENBERG, 1974, p. 21, nota 2, grifos no original). Se por um lado é difícil desprezar textos como os Grundrisse (MARX, 2011a), nos quais aparecem muitas indicações cronologicamente aquém do contato da China e da Índia com o capitalismo do século XVIII, por outro lado, um "desenvolvimento sistemático" contrasta decisivamente com a afirmação de que Marx não teria feito uma "construção elaborada" sobre o assunto.

Ao desconsiderarmos essa outra ambiguidade da analítica de Tragtenberg, podemos dizer que, de fato, Marx não possui um desenvolvimento sistemático porque este não foi o objeto central de suas investigações. Ele não buscava fazer historiografia pura ao sabor dos esquematismos frequentes. Suas análises das formas históricas dos modos de produção entravam inevitavelmente por uma série de razões, entre as quais indicamos, a partir da Introdução de 1857, a determinação do universal e do particular, do comum a todos os modos de produção e das diferenças específicas (cf. MARX, 2011a, p. 39-44), para destacar, por comparação, os elementos essenciais que marcam o modo de produção capitalista como particularidade histórica; enfim, sua lógica imanente que contém de maneira não acabada as condições de sua superação. Podemos ler também nos Grundrisse:

[...] o nosso método indica os pontos onde a análise histórica tem de ser introduzida, ou onde a economia burguesa, como simples figura histórica do processo de produção, aponta para além de si mesma, para modos de produção anteriores. Por essa razão, para desenvolver as leis da economia burguesa não é necessário escrever a história efetiva das relaçães de produção. Mas a sua correta observação e dedução, como relações elas próprias que devieram históricas, levam sempre a primeiras equações - como os números empíricos, p. ex., nas ciências naturais - que apontam para um passado situado detrás desse sistema. Tais indicações, juntamente com a correta apreensão do passado - um trabalho à parte, que esperamos também poder abordar. Por outro lado, esse exame correto também leva a pontos nos quais se delineia a superação da presente configuração das relações de produção - e, assim, o movimento nascente, a prefiguração do futuro. Se as fases pré-burguesas aparecem como simplesmente históricas, i.e., como pressupostos superados, de maneira que as condições atuais da produção aparecem abolindo a si mesmas e pondo-se, 
consequentemente, como pressupostos históricos para um novo estado de sociedade. (MARX, 2011a, p. 378-9, grifos no original).

Além desses dois momentos esclarecedores, Marx (2013, p. 151) também explica n'O capital que "[...] todo o misticismo do mundo das mercadorias [isto é, do modo de produção capitalista], toda a mágica e a assombração que anuviam os produtos do trabalho na base da produção de mercadorias desaparecem imediatamente, tão logo nos refugiemos em outras formas de produção". Disso resulta que as outras formas de produção servem à explicitação da diferença específica da produção capitalista. Por isso, não há uma “construção elaborada, como a que fizera a respeito do capitalismo" (TRAGTENBERG, 1974, p. 50).

Entretanto, somos forçados a deixar isso de lado, ainda que sob riscos, e enfrentar o desenvolvimento dado por Tragtenberg que, de alguma maneira, autonomiza o modo de produção asiático como objeto analítico para tratar da burocracia como categoria trans-histórica e não com o intuito de destacar a compreensão histórico-transitória do capitalismo. Então, se não é possível dissolver essa ambiguidade tragtenbergiana dada pelo contraste entre haver e não haver ao mesmo tempo um desenvolvimento da questão em Marx, fiquemos com a impressão de que Tragtenberg sustenta uma leitura problemática do modo de produção asiático e relativamente deslocada em relação às aquisições marxianas. Isso se reforça por outros pontos, como, por exemplo:

Entenda-se, a burocracia patrimonial pré-capitalista ou a capitalista representam categorias historicamente dadas cuja inteligibilidade é obtida através do estudo da especificidade do modo de produção asiático, escravista, feudal, capitalista. O que se quer colocar é o que as estruturas de dominação, ressalvados os dados de transitoriedade e especificidade, têm em comum: a separação entre o Estado e a sociedade civil, a burocracia e o súdito numa relação de dominação, ou dominação exploração (no modo asiático de produção), levando à Pacificação da existência social de que fala H. Marcuse. Tais comparações já haviam sido feitas por Marx, quando após ter descrito as condições econômico-sociais que permitiram a emergência do modo de produção asiático, fundado na cooperação simples do trabalho, finaliza: "Esse poder dos reis egípcios e asiáticos, dos teocratas etruscos e outros, na sociedade moderna transferiu-se para o capitalista, seja um capitalista isolado, ou, como num fundo de empresas reunidos, coletivo" (Bottomore, T. B. e Rubel, M. Sociologia e filosofia social de Karl Marx. São Paulo, Ed. Zahar, 1964, p. 113)”. (TRAGTENBERG, 1974, p. 21-2, nota 3, grifos no original).

Destacam-se duas questões. A primeira é considerar haver uma separação entre a dimensão política e a econômica em todo tipo de formação social, incluindo o modo de produção asiático. Para Hegel, assim como para Marx, a cisão entre essas esferas é um produto moderno e tal cisão real é pressuposto para a burocracia, como ainda veremos. A segunda, que reforça a leitura problemática de Tragtenberg acerca do modo de produção em tela, aparece na conjunção entre (i) a passagem "Esse poder dos reis egípcios e asiáticos" e (ii) a burocracia, fornecendo a conclusão de que tal poder é propriamente a burocracia, supostamente segundo um entendimento do próprio Marx. Mas o poder a que Marx se refere nesta passagem não é outra coisa senão, como ele mesmo escreve antes n' $O$ capital, "[...] o efeito da cooperação simples" que "[...] se apresenta de modo colossal nas obras gigantescas dos antigos asiáticos, egípcios, etruscos etc." (MARX, 2013, p. 409). O uso de versões diferentes pode ajudar a explicar essa imprecisão de Tragtenberg (cf. nota 2 deste artigo comparativamente com a nota anterior, pois dizem respeito ao mesmo e exato momento de $O$ Capital, porém reproduzidos de edições e traduções distintas). Todavia, esse contrabando da burocracia como poder de um Estado separado da sociedade é mais bem explicado por meio daquele amálgama entre Hegel e Marx (e Weber), donde parece se erigir uma identidade histórica inquebrantável entre Estado e burocracia imputada a Marx no tratamento do modo de produção asiático: 
Em 1853, em artigos publicados no Daily Tribune, Marx estuda o sistema urbano hindu e o baixo nível de divisão de trabalho dependendo da burocracia para a irrigação. Essa burocracia funda seus recursos na pilhagem interna e externa. Ela dirige uma sociedade vulnerável ao estrangeiro onde a mudança social é introduzida pelo colonialismo moderno. A chave explicativa deste modo de produção ele encontra na ausência da propriedade privada do solo, sendo o reino o único proprietário. (TRAGTENBERG, 1974, p. 53).

Tragtenberg explicita corretamente a ausência de propriedade privada no modo de produção asiático, forma de propriedade que, quando e se houve, desempenhava um papel secundário. No entanto, embora não seja possível desenvolver este ponto aqui, vale deixar indicado que Marx (1979; 1983b) prefere sempre "Estado" e "governo" e, salvo o melhor juízo, não emprega na terminologia a palavra "burocracia" ao se referir aos modos de produção pré-capitalista (a não ser quando o assunto era a monarquia absolutista; cf. MARX, $2011 \mathrm{~b} ; 2011 \mathrm{c}$, e a nota 4 deste presente artigo). É preciso, pois, atentar para a cautela sugerida por GODELIER (1972, p. 62) a este respeito. Os efeitos daquele amálgama podem ser cada vez mais explicitados, sobretudo porque Tragtenberg desenvolve o fio condutor que o levará à conclusão de que é o Estado que gera a sociedade civil nas sociedades que de alguma forma mantêm proximidade ao padrão societal do modo de produção asiático, o que inclui, desse ponto de vista, a antiga União Soviética:

Vimos que a emergência da burocracia patrimonial como poder político nas sociedades orientais e pré-colombiana antecede de muito o aparecimento da burocracia funcional da indústria moderna, confirmando o aforismo hegeliano de que a substância do Estado é a realização do interesse universal enquanto tal (da burocracia). Isso se dá na URSS, Europa Oriental e nos países de autocracia modernizante. O Estado aparece como triunfo da razão hegeliana, onde a maturidade política é conquistada por mediação da burocracia, que introduz a unidade, na diversidade da sociedade civil. O Estado como burocracia acabada gera a sociedade civil, o regresso de Marx a Hegel. (TRAGTENBERG, 1974, p. 44, grifos no original).

A confirmação do aforismo hegeliano para um regresso de Marx a Hegel arma-se conjuntamente à identidade inquebrantável entre Estado e burocracia, ao contrabando desta para o modo de produção asiático por meio do amálgama entre os autores, mas também se arma conjuntamente a uma leitura problemática e ainda em desenvolvimento das determinações marxianas que aquelas ambiguidades e imprecisões textuais deixam entrever. E aqui aparece com todas as letras a problemática que enfrentamos. Não por menos, identificamos no último capítulo de Burocracia e ideologia a plena transitividade entre Hegel e Marx: “[...] quando definimos a volta de Marx a Hegel, definimos uma relação de continuidade Hegel-Marx. Da mesma forma que este fornecera a Marx o método dialético, fornecera também esquemas explicativos que permitem situar o papel legitimador da burocracia enquanto classe dominante" (TRAGTENBERG, 1974, p. 188).

A burocracia aparece então como classe e instrumento de legitimação de si mesma e Marx como herdeiro do "método dialético" e também dos "esquemas explicativos" que determinam esse duplo caráter da burocracia. "Em suma", completou Tragtenberg, a burocracia "une a sociedade civil ao Estado, efetua a viagem de volta de Marx a Hegel, converte sua razão histórica na razão na história, do contingente passa à essencialidade" (TRAGTENBERG, 1974, p. 190, grifos no original). Sem mencionar as problemáticas ligadas à herança de um "método dialético" e de "esquemas explicativos" tão transitivamente postos (como veremos no próximo tópico), não é muito difícil capturar a existência de rastros de um idealismo nesse fio condutor que trouxe Tragtenberg a essas conclusões. Percebe-se também que aquela identidade inquebrantável entre Estado e burocracia agora se abranda brevemente para que a burocracia possa assumir duplo caráter, isto é, ser a burocracia e, ao mesmo tempo, o próprio Estado e mediação entre o Estado e a sociedade. Tal caráter é claramente derivado de um problemático silogismo hegeliano, quer dizer, a relação lógico-formal entre Estado (universalidade), burocracia (termo médio) e sociedade civil (singularidade) (cf. PAÇO-CUNHA, 
2013) que não reproduz a "lógica da coisa", mas apenas se resume numa "coisa da lógica" (MARX, 2005, p. 39). A via especulativa tragtenbergianamente posta se mostra com toda inteireza.

A despeito dos problemas secundários, passa a ser importante destacar os dois pontos centrais que aqui constatamos, conforme adiantado brevemente na introdução: 1. a cisão entre Estado e sociedade civil; fórmula hegeliana para a relação entre Estado e sociedade já no desenvolvimento do capitalismo e que Tragtenberg lança para o modo de produção asiático; 2. a solução especulativa de considerar que o Estado gera a sociedade, tendo por condição o alegado regresso de Marx a Hegel ou de continuidade Hegel-Marx. No próximo tópico enfrentamos as duas questões mais detidamente.

\section{A Superação de Hegel por Marx e a Determinação Ontológica da Relação entre Estado e Sociedade}

Tragtenberg realiza uma vasta leitura dos materiais marxianos que tangenciam o modo de produção asiático, mas submetida a um operatório marcado pela "interpretação e associação nova de ideias" como adiantamos no tópico anterior. Frente a isso, o ponto de partida dado pelo "nível lógico-histórico", aparentemente centrado em Marx, perde força para o "nível lógico" (Hegel) e, aos poucos, revela-se ainda mais problemático também por desconsiderar o lugar da análise dos modos de produção pré-capitalista na análise marxiana do capitalismo, como veremos neste tópico.

Antes, porém, vemos que a solução de Tragtenberg pelo aforismo hegeliano está derradeiramente ligada à suposta continuidade entre Hegel e Marx, tendo este como um autêntico herdeiro dos "esquemas explicativos" da burocracia e também herdeiro da dialética hegeliana, como vimos antes. Isso impõe exigências. Assim, antes de aprofundarmos as questões decisivas no tocante à cisão entre Estado e sociedade no modo de produção asiático e também à relação de pressuposição (ontológica) entre eles, são necessárias algumas palavras sobre aquela plena transitividade posta pelo autor brasileiro porque, além de estar relacionada com nosso problema central, ajuda a dar provas mais concretas da superação de Hegel por Marx ao invés de uma "continuidade Hegel-Marx" como prefere Tragtenberg.

Sem que seja necessário desenvolver longamente a questão (e ela é múltipla), o jovem Lukács (antes apenas aludido) talvez seja o melhor e maior exemplo dessa problemática transitividade entre Hegel e Marx. Em parte convencido pela famosa afirmação de Lenin (2011, p. 157) de que "[...] não se pode compreender plenamente $O$ capital de Marx, e particularmente o seu primeiro capítulo, sem ter estudado e compreendido toda a Lógica de Hegel", e em parte influenciado por sua própria formação no território hegeliano, escreveu História e consciência de classe (publicada em 1923), em relação à qual teceu autocrítica anos depois (em 1967), declarando no prefácio ter havido marcas de um "exagero hegeliano" (LUKÁCS, 2003, p. 21) - sem mencionar a relação ambígua que manteve com as ideias weberianas e que permaneceu sem a mesma autocrítica direta (cf. PAÇO-CUNHA, 2012). Com isso queremos destacar que essa aproximação exagerada entre Marx e Hegel não é algo que se dê sem problemáticas e perdas para o próprio pensamento marxiano, por torná-lo artificialmente dependente das elaborações especulativas hegelianas (cf. CHASIN, 2009, p. 176 e nas páginas seguintes) e nem se confirma como algo exclusivamente encontrado em Burocracia e ideologia. Ao comentar criticamente essa aproximação exagerada dada por Lukács, Chasin explica o quão malsucedido foi o intento (presente também em LUKÁCS, 1978) "[...] de estabelecer um denso vínculo lógico entre Marx e Hegel, exatamente porque não há como ligar esses dois autores, no plano lógico, por meio de arrimos textuais diretos, não só porque estes efetivamente inexistem, mas também porque os pronunciamentos marxianos a respeito desautorizam essa velha hipótese" (CHASIN, 2009, p. 177).

O resultado mais direto dessa "velha hipótese" é converter Marx numa espécie de mero aplicador das ilações abstratas de Hegel aos diferentes problemas da existência social como se o próprio Marx não estivesse plenamente consciente dos problemas envolvidos. Tenhamos em mente, no entanto, a restrição de Marx quando escreveu em 1847: "[...] o que Hegel fez em relação à religião, ao direito, etc., o Sr. Proudhon procura fazer em relação à economia política" (MARX, 1985, p. 104), isto é, dar vazão ao pensamento puro, à razão impessoal, destacado da vida efetiva dos homens reais. Ou, como resultado numa forma derivada, é converter Marx num herdeiro de "esquemas explicativos" daquele duplo caráter da burocracia. 
Mas uma compreensão mais apurada não apenas impede esse redutor como também indica "[...] o caráter e o momento preciso da inflexão intelectual a partir da qual [Marx] passa a elaborar seu próprio pensamento" (CHASIN, 2009, p. 57). Ao invés de uma continuidade Hegel-Marx, "[...] trata-se de uma viragem ontológica que a leitura de Crítica da filosofia do direito de Hegel comprova indubitavelmente [...]", pois "[...] é o início do traçado de uma nova posição ontológica que os textos subsequentes [...] confirmam, reiteram e desenvolvem num largo e complexo processo de elaboração" (p. 57). Essa "viragem ontológica" marca a linha a partir da qual podemos identificar os movimentos iniciais da elaboração autenticamente marxiana que se deu pela retomada crítica de Hegel, conforme nos esclarece Marx (1974) em seu Prefácio autobiográfico, particularmente ao problema do Estado. A leitura dessa Crítica de 1843 (MARX, 2005) comprova que "[...] em contraste radical com a concepção do Estado como demiurgo racional da sociabilidade, isto é, da universalidade humana, [...], irrompe e domina agora, para não mais ceder lugar, a 'sociedade civil' - o campo da interatividade contraditória dos agentes privados, a esfera do metabolismo social - como demiurgo real que alinha o Estado e as relações jurídicas. Inverte-se, portanto, a relação determinativa" conforme se apresenta pela filosofia especulativa hegeliana. Agora, em Marx:

[...] os complexos reais envolvidos [sociedade e Estado] aparecem diametralmente reposicionados um em face do outro. Mostram-se invertidos na ordem da determinação pela força e peso da lógica imanente a seus próprios nexos, não em consequência formal e linear de algum pretensioso volteio especial nos arranjos metodológicos, isto é, não como resultante de uma simples e mera reorganização da subjetividade do pesquisador, mas por efeito de uma trama reflexiva muito mais complexa, que refunde o próprio caráter da análise, elevando o procedimento cognitivo à analítica do reconhecimento do serprecisamente-assim. (CHASIN, 2009, p. 58)

A apreensão da "lógica imanente" e dos "próprios nexos" da relação entre sociedade e Estado compreende o "reconhecimento do ser-precisamente-assim", isto é, a partir da trama própria da coisa efetivamente existente, nos seus enlaces de reciprocidade e, antes, de pressuposição ontogenética, determinada na processualidade real historicamente contraditória. Mas isso tudo não significa um simples corte, um salto puro de Marx em relação às aquisições hegelianas (e também, de modo específico, em relação às aquisições de Feuerbach, cf. CHASIN, 2009). Importa destacar o reconhecimento marxiano de que, a despeito da fórmula especulativa que submete a realidade efetiva aos nexos de uma lógica formal, "Hegel costuma oferecer, dentro da exposição especulativa, uma exposição real, através da qual é possível capturar a própria coisa" (MARX, 2003, p. 75). Anos mais tarde, Marx mesmo indicou a existência do "[...] cerne racional dentro do invólucro místico" (MARX, 2013, p. 91) na filosofia hegeliana. Seria ingenuidade e imprecisão considerar o desenvolvimento marxiano independente da filosofia idealista, mas problema maior é afirmar uma plena continuidade como quer Tragtenberg. Dado o "cerne racional", dada a existência de uma "exposição real" dentro da "exposição especulativa":

[...] melhor será dizer que Marx terá se apropriado de alguns resultados [historicidade, processualidade, contradição etc.], mas contra os rumos e os meios pelos quais certas conquistas hegelianas se efetivaram [...] porque um dos traços mais característicos da posição ontológica instaurada por Marx é a ruptura com a especulação ou qualquer modo apriorista de elaboração teórica. (CHASIN, 2009, p. 216-7).

Este momento também é oportuno para trazer as palavras de Marx mais diretamente sobre a dialética, ainda que o material por nós utilizado se resuma a $O$ capital. São palavras bastante conhecidas aquelas que Marx escreveu sobre seu "método dialético, em seus fundamentos, não [ser] apenas diferente do método hegeliano, mas exatamente seu oposto" (MARX, 2013, p. 90), isto é, a historicidade, a processualidade, a contradição etc. operam aqui de modo particular. Mas isso não afasta o reconhecimento de que "[...] a mistificação que a dialética sofre nas mãos de Hegel não impede em absoluto que ele tenha sido o primeiro a expor, de modo amplo e consciente, suas formas gerais de movimento" (p. 91). Qual mistificação, centralmente? É que "[...] 
para Hegel, o processo de pensamento, que ele, sob o nome de Ideia, chega mesmo a transformar num sujeito autônomo, é o demiurgo do processo efetivo, o qual constitui apenas a manifestação externa do primeiro" (p. 90). Este caráter mistificador da dialética nas mãos de Hegel, encontrado até mesmo na determinação da Ideia de Estado como anterioridade (o que veremos logo em seguida), impede a compreensão de que o próprio processo efetivo é o autêntico demiurgo. Processo esse que comporta a contradição, a historicidade etc. de um modo específico, qual seja, segundo a lógica imanente, o ser-precisamente-assim da materialidade, a "própria coisa". Não é por outro motivo que a "[...] investigação tem de se apropriar da matéria em seus detalhes, analisar suas diferentes formas de desenvolvimento e rastrear seu nexo interno" ( $p$. 90), como ensinou Marx em contraste com aquela mistificação.

Em suma, aquela "continuidade Hegel-Marx" encontra em Marx o seu primeiro e maior opositor. E isso fica ainda mais decisivamente posto ao encaminharmos por meio dessas considerações - as quais demarcam a viragem ontológica e, ao mesmo tempo, a superação de Hegel por Marx - aqueles dois problemas importantes à nossa problemática.

O primeiro ponto a ser destacado, e que remete aos problemas postos acima, é, portanto, o aspecto da separação entre Estado e sociedade civil que Tragtenberg universaliza com base nas considerações hegelianas. O próprio Hegel determina tal cisão como um produto moderno, não obstante os problemas da filosofia especulativa. Antes de mais nada, é importante considerar a conhecida formulação hegeliana (cf. HEGEL, 2010) de anterioridade do Estado enquanto Ideia que veio a ser Estado concreto como produção racional e não contraditório, por meio dos momentos finitos ao longo da história (propriedade, contratos, família e, finalmente, sociedade civil). O Estado como resultado da história é prova de que já existia como pressuposto na forma do conceito, pois, em termos de uma lógica formal, "[...] na marcha do conceito científico, o Estado aparece como resultado, visto que ele se mostra como o fundamento verdadeiro" (HEGEL, 2010, §256, p. 228-9, grifos no original). A esta formulação Marx teceu duras críticas pela apreensão de se tratar de um "[...] misticismo lógico, panteísta" (MARX, 2005, p. 29, grifos no original), pois, entre outras coisas, não parte dos homens reais, das relações efetivas entre os homens, constituindo-se num "[...] pensamento extravagante e abstrato acerca do Estado moderno" (p. 151, grifo no original).

Em segundo lugar, este Estado como produto de uma razão supra-humana põe a si mesmo como ser autodeterminado em oposição à sociedade civil (porque se faz a si mesmo como Ideia já existente). O Estado como universalidade e a sociedade civil(-burguesa - bürgerliche Gesellschaft) como o plano da luta de todos contra todos, das carências e do egoísmo. Por isso, lemos em Hegel que "[...] os interesses particulares comunitários, que recaem na sociedade civil-burguesa e residem fora do universal sendo em si e para si do Estado mesmo (\$256), têm sua administração nas corporações (\$251) das comunas e dos demais ofícios e estamentos, e em suas autoridades, dirigentes, administradores e semelhantes. [...]" (HEGEL, 2010, §288, p. 272, grifo no original). Os elementos que Hegel mobiliza dão provas de se tratar do momento especificamente moderno, isto é, já na sociabilidade marcada pelo capital, mas com os resquícios ainda feudais notáveis na Prússia da época. Não por menos Marx reconhece criticamente a exatidão hegeliana, o "cerne racional" dentro da "exposição especulativa", em expressar tal produto hodierno ao escrever que "[...] a abstração do Estado como tal pertence somente aos tempos modernos porque a abstração da vida privada pertence somente aos tempos modernos. A abstração do Estado político é um produto moderno" (MARX, 2005, p. 52, grifos no original). A separação entre a vida material na esfera da sociedade civil e o cidadão no céu do Estado (uma dupla vida) é um dado concreto da existência social já no modo capitalista de produção (cf. MARX, 2010). Isso fica ainda mais explícito quando lemos:

Mas Hegel parte da separação da 'sociedade civil' e do 'Estado político' como de dois opostos fixos, duas esferas realmente diferentes. De fato, essa separação é, certamente, real no Estado moderno. A identidade dos estamentos civil e político era a expressão da identidade das sociedades civil e política. Essa identidade desapareceu. Hegel a pressupõe como desaparecida. Se a identidade dos estamentos civil e político expressasse a verdade, ela não poderia ser, portanto, mais do que uma expressão da separação das sociedades civil e política! Ou ainda: somente a separação dos estamentos civis e dos estamentos políticos 
exprime a verdadeira relação entre as modernas sociedades civil e política. (MARX, 2005, p. 89-90).

A identidade, comum a épocas passadas, desapareceu. Hegel a supõe como desaparecida e de fato, diz Marx, esta é uma expressão da relação entre as modernas sociedades e a política. De maneira complementar, podemos ler que "Hegel parte da separação entre 'Estado' e sociedade 'civil', entre os 'interesses particulares' e o 'universal que é em si e para si', e a burocracia está, de fato, baseada nessa separação" (MARX, 2005, p. 64).

O conjunto nos permite então perguntar: se Tragtenberg tinha à disposição, como também chegou a empregar os materiais de Hegel e Marx a este respeito (cf. PAÇO-CUNHA, 2013), por que veio, como vimos, a determinar essa cisão como algo também típico do modo de produção asiático? Por meio de Marx, no entanto, fica estabelecida a dificuldade própria à filosofia especulativa hegeliana de um termo médio (burocracia), que também é extremo universal (Estado), mediar sua própria relação (como extremo e meio termo ao mesmo tempo) com o polo oposto (sociedade) (cf. MARX, 2005, p. 104-5). O (falso) universal (Estado) é mediado por si mesmo além de ele próprio engendrar o seu contrário! Existe aqui a persistência de uma mistificação que Marx muito bem identificou em Hegel e que Tragtenberg prolonga para modos de produção passados.

Mesmo em $O$ Capital (e tendo em mente os limites dos materiais etnológicos disponíveis à época), Marx insinua como as dominações econômica e política davam-se indistintamente em modos de produção précapitalistas, sugerindo a não separação autêntica entre Estado e sociedade. Por exemplo, ao indicar que no modo de produção asiático, diferentemente do capitalista, a transformação dos produtos em mercadorias desempenhava um papel subordinado na vida social, escreve que:

Esses antigos organismos sociais de produção são extraordinariamente mais simples e transparentes do que o organismo burguês, mas baseiam-se ou na imaturidade do homem individual, que ainda não rompeu o cordão umbilical que o prende a outrem por um vínculo natural de gênero [Gattungszusammenhangs], ou em relações diretas de dominação e servidão. Eles são condicionados por um baixo grau de desenvolvimento das forças produtivas do trabalho e pelas relações correspondentemente limitadas dos homens no interior de seu processo material de produção da vida, ou seja, pelas relações limitadas dos homens entre si e com a natureza. (MARX, 2013, p. 154).

Relações diretas de dominação e servidão expressam indiretamente uma não autêntica separação do complexo político em relação ao econômico, uma vez que a dominação econômica é também política e viceversa neste caso. Os laços, por exemplo, entre os membros e o déspota como o grande pai também são indicativos da dependência pessoal, e o poderoso efeito já mencionado da cooperação simples na produção das grandes obras denota isso. Podemos somar outra passagem importante a este respeito:

A cooperação no processo de trabalho tal como a encontramos predominantemente nos primórdios da civilização humana, entre os povos caçadores ou, por exemplo, na agricultura da comunidade indiana, baseia-se, por um lado, na propriedade comum das condições de produção e, por outro, no fato de que o indivíduo isolado desvencilhou-se tão pouco do cordão umbilical da tribo ou da comunidade quanto uma abelha da colmeia. Essas duas características distinguem essa cooperação da cooperação capitalista. A aplicação esporádica da cooperação em grande escala no mundo antigo, na Idade Média e nas colônias modernas repousa sobre relações imediatas de domínio e servidão, principalmente sobre a escravidão. A forma capitalista, ao contrário, pressupõe desde o início o trabalhador assalariado, livre, que vende sua força de trabalho ao capital. Historicamente, porém, ela se desenvolve em oposição à economia camponesa e à produção artesanal independente, 
assumindo esta última a forma da guilda ou não. Diante delas, não é a cooperação capitalista que aparece como uma forma histórica específica da cooperação, mas, ao contrário, é a própria cooperação que aparece como uma forma histórica peculiar do modo de produção capitalista, como algo que o distingue especificamente. (MARX, 2013, p. 409).

Propriedade comum e ligação umbilical do indivíduo em relação à comunidade caracterizam a cooperação no modo de produção asiático, o qual repousa sobre "relações imediatas de domínio". No interior dessas relações, como veremos adiante, o indivíduo é escravo num sentido muito especial. Diferentemente dessa forma de propriedade e da relação do indivíduo com sua comunidade, a produção capitalista funda-se e reproduz o trabalho duplamente livre (sem qualquer propriedade sobre meios de produção e livre das amarras da servidão e da escravidão, cf. MARX, 2013, p. 787 e nas páginas seguintes). Com isso explicita-se a cisão entre as esferas política e econômica que acompanha o processo por meio do qual o capitalismo se desenvolveu, isto é, o processo de separação entre trabalho e propriedade dos meios de produção. $\mathrm{O}$ resultado, mas não apenas como um epifenômeno, foi o reconhecimento do fato na abstração jurídicoburguesa, posterior à separação entre propriedade e trabalho. Nessa expressão jurídica heterônoma (uma vez que não expressa a coisa como tal) surge o cidadão abstrato como proprietário da força de trabalho e livre para aliená-la a despeito da relação efetiva de exploração do trabalho pelo capital. Esta relação efetiva segue persistente sob a aparência de troca que a expressão jurídica ajuda a consolidar (cf. MARX, 2013, p. 250-1). No modo capitalista de produção, a dominação econômica é pressuposto deste reflexo jurídico nas "alturas" do Estado, reflexo este muito precário ou inexistente no modo de produção asiático devido às fortes ligações do indivíduo com a comunidade; ou, dito de outra maneira, não havia condições econômicas suficientemente desenvolvidas para que se desse uma abstração da vida real no céu da política: fundamentalmente, não estava desenvolvido o trabalho abstrato produtor de mercadorias e os indivíduos relacionavam-se, antes de tudo, como membros de uma comunidade e não como livres proprietários.

Dessa maneira, a cisão entre trabalho e propriedade, pressuposto do reflexo jurídico no capitalismo, está em flagrante contraste com a dominação existente no modo de produção asiático, no qual a propriedade privada não desempenhava o papel central e cuja forma de dominação era marcada por um profundo e também problemático vínculo do indivíduo à comunidade, que impedia o desenvolvimento da individualidade. A cisão entre Estado e sociedade tem também por pressuposto, portanto, a natureza da relação entre trabalho e propriedade, de modo que apenas uma sociedade em que o trabalho aparece formalmente livre pode gerar as condições econômicas de uma autonomização mais efetiva e duradoura da comunidade política para o céu do Estado. E isto como resultado de longos processos de luta social no interior da sociedade, inclusive por mediação do próprio complexo político formado na sociabilidade do capital (aquisição de direitos, políticas sociais, por exemplo). Por isso, não se deve confundir a autonomia relativa da esfera política no modo de produção asiático com uma separação ou abstração real como produto do desenvolvimento progressivo do capital. O trabalho livre, liberto da propriedade e dos laços de dependência, é condição para uma abstrata vida política, radicalmente cindida em relação à sociedade, de maneira que o indivíduo leve de fato, cotidianamente, uma dupla vida: de um lado, o cidadão abstrato; de outro, o "livre" trocador de mercadorias, como indica Marx (2010); lá a igualdade abstrata, aqui a desigualdade real. No modo de produção asiático, o indivíduo não se apresenta isolado, suficientemente descolado da comunidade. Vemos, pois, as problemáticas consequências ao se autonomizar a análise dos modos de produção passados em relação à "anatomia da sociedade civil" (MARX, 1974, p. 135), isto é, a sociabilidade do capital.

Todavia, essas considerações não têm qualquer pretensão de esgotar o problema, menos ainda hipostasiar as relações econômicas e considerar a formação de Estado mero epifenômeno como muitas vezes se repetiu por um marxismo vulgar. Ao contrário, apenas tangenciamos a questão explicitando que o Estado tem por pressuposto as relações materiais e é engendrado por elas, antes de ter sobre elas mesmas qualquer efeito. O que marca, portanto, o modo de produção asiático são suas relações materiais caracteristicamente de baixa mutabilidade, a despeito das formas e mudanças políticas, o que não deve ser visto como índice de cisão autêntica entre os complexos reais da sociabilidade. Vejamos esse aspecto mais de perto, o que nos ajudará a 
indicar a formação de Estado a partir das relações materiais e como estas não são necessariamente alteradas pelas diferentes formações de Estado.

Nessa direção, Marx desenvolve, em alguma medida nos Grundrisse, as determinações fundamentais dessas relações e as variabilidades das formas políticas. No modo de produção asiático, a produção de mercadorias é uma atividade subordinada. Estamos diante de uma sociabilidade na qual "[...] a produção de valores de uso é a finalidade econômica" (MARX, 2011a, p. 397), em que "[...] o produto excedente [...] pertence por si só à unidade suprema" (2011a, p. 389) na forma da renda do Estado (e não do lucro ${ }^{5}$ por meio dos impostos, e em que "[...] a terra é o grande laboratório, o arsenal, que fornece tanto o meio de trabalho quanto o material de trabalho, bem como a sede, a base da comunidade" (p. 389, grifo no original). Em seguida, completou Marx:

Eles se relacionam com terra, ingenuamente, como propriedade da comunidade, e da comunidade que se produz e reproduz pelo trabalho vivo. Somente como parte, como membro dessa comunidade, cada indivíduo singular se comporta como proprietário ou possuidor. A apropriação real pelo processo do trabalho se realiza sob esses pressupostos, que não são eles mesmos produto do trabalho, mas aparecem como seus pressupostos naturais ou divinos. Essa forma, em cuja base está a própria relação fundamental, pode realizar-se de maneiras muito variadas. (MARX, 2011a, p. 389, grifos no original).

Guardando o destaque para a resolução de que aquele processo de trabalho historicamente determinado tem por pressuposto a propriedade comum e o indivíduo como detentor da posse por ser membro da comunidade, Marx, com base nisso, analisa algumas variações que podem apresentar a "[...] forma mais despótica ou democrática dessa comunidade" (MARX, 2011a, p. 390), as quais têm por base essa relação de não proprietário individual. Tendo em mente uma dessas exemplificações, escreveu Marx:

Por exemplo, não a contradiz de maneira alguma o fato de que, como na maioria das formas asiáticas fundamentais, a unidade coletiva que se situa acima de todas essas pequenas comunidades apareça como o proprietário supremo ou o único proprietário, ao passo que as comunidades reais apareçam apenas como possuidoras hereditárias. Sendo a unidade o proprietário real e o pressuposto real da propriedade comunitária, essa própria unidade pode aparecer como um particular acima das numerosas comunidades particulares reais, em que o indivíduo singular é então de fato privado de propriedade, ou em que a propriedade - i.e., a atitude do indivíduo em relação às condições naturais do trabalho e da reprodução como pertencendo a ele, como o corpo objetivo, natureza inorgânica dada, de sua subjetividade aparece-lhe mediada pela concessão [Ablassen, e não supressão como aparece na tradução brasileira] da unidade geral, que é realizada no déspota como o pai das muitas comunidades, e no indivíduo singular, pela mediação da comunidade particular. (MARX, 2011a, p. 389; 1983a, p. 385, grifos no original).

\footnotetext{
5 "Certa acumulação ocorre em todas as fases do desenvolvimento econômico, isto é, quer ampliação da escala de produção, quer entesouramento etc. Enquanto predominam salário e renda fundiária - isto é, conforme já se viu antes, enquanto cabe ao dono da terra (ao Estado na Ásia) a maior parte do trabalho excedente e do produto excedente que em geral não revertem para o próprio trabalhador, e, além disso, enquanto o próprio trabalhador reproduz seu fundo de trabalho, ou seja, não só produz seu próprio trabalho, mas ainda o paga a si mesmo, com o que em regra fica em posição (nesse estádio da sociedade, quase sempre) de se apropriar também de parte pelo menos de seu trabalho excedente e de seu produto excedente -, salário e renda fundiária nesse estádio da sociedade também são as principais fontes de acumulação. (Lucro aí se restringe a comerciantes etc.) Só depois de a produção capitalista se tornar a dominante, de existir não esporadicamente, mas de subordinar a si mesma o modo de produção da sociedade; depois de o capitalista se apropriar na realidade de todo o trabalho excedente e do produto excedente na primeira instância, embora tenha de entregar porções dele ao dono da terra etc., só a partir daí, o lucro se torna a fonte principal do capital, com o objetivo de lucro". (MARX, 1980-1985, p. 1461).
} 
E, adicionou, pouco depois, que "[...] as condições coletivas da apropriação efetiva por meio do trabalho, os aquedutos, muito importantes entre os povos asiáticos, os meios de comunicação etc., aparecem então como obra da unidade superior - do governo despótico pairando acima das pequenas comunidades" (2011a, p. 389; 1983a, p. 385, grifos no original), uma vez que essas grandes obras, efeito da cooperação simples, requeriam um governo centralizado para levá-las adiante. Fica patente que esse governo centralizado cumpria um papel importante nesse modo de produção (como Tragtenberg muito bem capturou), particularmente em sua forma despótica:

There have been in Asia, generally, from immemorial times, but three departments of Government; that of Finance, or the plunder of the interior; that of War, or the plunder of the exterior; and, finally, the department of Public Works. Climate and territorial conditions, especially the vast tracts of desert, extending from the Sahara, through Arabia, Persia, India, and Tartary, to the most elevated Asiatic highlands, constituted artificial irrigation by canals and water-works the basis of Oriental agriculture. As in Egypt and India, inundations are used for fertilising the soil in Mesopotamia, Persia, \&c.; advantage is taken of a high level for feeding irrigative canals. This prime necessity of an economical and common use of water, which, in the Occident, drove private enterprise to voluntary association, as in Flanders and Italy, necessitated, in the Orient where civilization was too low and the territorial extent too vast to call into life voluntary association, the interference of the centralizing power of Government. Hence an economical function devolved upon all Asiatic Governments, the function of providing public works. This artificial fertilisation of the soil, dependent on a Central Government, and immediately decaying with the neglect of irrigation and drainage, explains the otherwise strange fact that we now find whole territories barren and desert that were once brilliantly cultivated, as Palmyra, Petra, the ruins in Yemen, and large provinces of Egypt, Persia, and Hindostan; it also explains how a single war of devastation has been able to depopulate a country for centuries, and to strip it of all its civilisation (MARX, 1979, p. 127).

Vemos que, como antes, o governo central promove obras públicas as quais, de outra forma, em razão do nível das forças produtivas e da vastidão territorial, não poderiam ser realizadas. Novamente, as condições econômicas, mas também ambientais, influem na formação de Estado, cuja ausência, no caso, impediria a expansão para outras áreas por meio da criação de zonas irrigadas e novas cidades nessas zonas. Reconhecer isto, no entanto, não é o mesmo que supor que o Estado tenha a potência geradora da sociedade no modo de produção asiático porque, ao contrário, tem nela seus pressupostos, isto é, um tipo específico de relacionamento do indivíduo com a comunidade, aquele enquanto não proprietário privado e essa, como veremos em seguida, na qualidade de um mundo autossuficiente. Em suma, é preciso fazer distinção entre as relações de reciprocidade e aquelas de pressuposição objetiva, em que as últimas são condição para as primeiras. Tragtenberg parece ter tomado a reciprocidade por pressuposição, o que resultou na solução posta de que o Estado gera a sociedade nesse modo de produção particular.

Enquanto em outros modos de produção mudanças são engendradas pela introdução da escravidão ou servidão, no modo de produção asiático, escreveu Marx, "[...] o indivíduo singular jamais se torna proprietário, mas só possuidor, no fundo ele próprio é a propriedade, o escravo daquilo em que existe a unidade da comunidade, e, nesse caso, a escravidão não abole as condições de trabalho nem modifica a relação essencial" (MARX, 2011a, p. 404). A condição social de escravo, aqui, tem, portanto, uma coloração especial porque o indivíduo não faz parte dos meios de produção e não pode ser alienado, como no uso dos escravos na produção antiga (instrumentos que falam) encontrada na Grécia. Tal relação essencial é persistente por uma série de razões e elas ajudam a explicar por que, em última instância, não é o Estado que gera a sociedade no modo de produção asiático. Na verdade esse operatório especulativo para o qual Tragtenberg direcionou sua análise ao acatar o aforismo hegeliano não descreve movimento real e histórico algum a não ser no plano lógico. 
Com efeito, em 1853 escreveu Marx a Engels uma carta esclarecendo que tal natureza persistente dessas formações sociais, a despeito de toda a "[...] atividade da superfície política, pode ser explicada por duas circunstâncias mutuamente implicadas: 1. O sistema de obras públicas de um governo central e 2. Em paralelo, um império inteiro que, além de poucas grandes cidades, é formado por um aglomerado de vilas, cada qual com sua organização distinta e formando seu próprio pequeno mundo" (MARX, 1983b, p. 346-7, grifos no original). Entre 1857 e 1859, escreveu Marx que essa persistência se deve "[...] ao seu pressuposto", isto é, "[...] que o indivíduo singular não devém autônomo em relação à comunidade" e "[...] que há um círculo da produção autossustentável, unidade de agricultura e manufatura etc." (MARX, 2011a, p. 398). Fica indicada a existência de outros elementos constitutivos desse pressuposto (com o "etc." ao final da última frase), aos quais não necessariamente se soma o governo centralizado porque, como vimos, esse traço, além de dizer mais coisas sobre determinadas formas do modo de produção asiático, isto é, as suas formas particularmente despóticas, é explicativo não isoladamente de certa imutabilidade, por assim dizer, dessas formações. Nesta forma em particular, despótica, disse Marx em outro lugar, "[...] o trabalho de superintendência e ingerência do governo em todos os aspectos compreende ambas as coisas: tanto a realização das tarefas comuns, que derivam da natureza de toda a comunidade, como as funções específicas, aquelas que emergem do antagonismo do governo para com a massa do povo" (MARX, 1962, p. 397). Tais funções, portanto, nada idílicas, demarcam a forma de dominação econômico-política que prevalece no modo de produção asiático ao lado das obras públicas. Confirmam-se, novamente, as decisivas funções da formação de Estado nesse modo de produção, mas isso nada tem a ver com o Estado enquanto demiurgo da sociedade ou como seu pressuposto real nos termos de um aforismo idealista modificado como aquele estabelecido por Tragtenberg. Logo, o reconhecimento desse lugar do Estado, particularmente no que tange às grandes obras, não o torna pressuposto objetivo da existência das comunidades autossuficientes. Como aventado antes, tudo indica que Tragtenberg converteu a relação de reciprocidade entre Estado e sociedade em que o primeiro tem efetivamente um peso até mesmo nas funções antagônicas em relação à sociedade numa relação de determinação causal, elevando a dimensão política à causa primária da sociedade. Do ponto de vista da materialidade mesma, do ser-propriamente-assim, é insustentável tal conversão. E isso ainda fica mais patente se avaliarmos, com Marx, o efeito do imperialismo inglês sobre a Índia:

These small stereotype forms of social organism have been to the greater part dissolved, and are disappearing, not so much through the brutal interference of the British tax-gatherer and the British soldier, as to the working of English steam and English free trade. Those family-communities were based on domestic industry, in that peculiar combination of handweaving, hands-spinning and hand-tilling agriculture which gave them self-supporting power. English interference having placed the spinner in Lancashire and the weaver in Bengal, or sweeping away both Hindoo spinner and weaver, dissolved these small semibarbarian, semi-civilized communities, by blowing up their economical basis, and thus produced the greatest, and to speak the truth, the only social revolution ever heard of in Asia. (MARX, 1979, p. 131)

A verdadeira revolução imperialista engendrada pela invasão inglesa não foi a eliminação ou alteração do Estado despótico, mas a destruição da base econômica. Se o Estado pode ser eliminado e se, ainda assim, persistem as relações de produção até que sejam destruídas, particularmente nessa fase imperialista do capital, apreendemos conclusivamente que, não obstante as funções importantes do governo centralizado e os efeitos problemáticos quando tais funções cessam - desocupação de vastas áreas por falta de irrigação, por exemplo -, ele não se confirma como pressuposto necessário das comunidades isoladas, as quais podem manter as suas bases econômicas intactas, mais ou menos imunes às alterações na formação de Estado. Esse problema se resolve relativamente por uma passagem de $O$ Capital, presente no capítulo sobre a Divisão do trabalho e a manufatura. Marx discute a reciprocidade entre a divisão social do trabalho e a divisão social na sociedade quando escreve:

Se na sociedade do modo de produção capitalista a anarquia da divisão social do trabalho e o despotismo da divisão manufatureira do trabalho se condicionam mutuamente, as formas 
sociais anteriores - nas quais a particularização dos ofícios se desenvolve espontaneamente, depois cristaliza-se e, por fim, consolida-se por lei - apresentam, por um lado, o quadro de uma organização do trabalho social submetida a um planejamento e a uma autoridade, enquanto, por outro, excluem inteiramente a divisão do trabalho na oficina, ou só a desenvolvem numa escala ínfima, ou ainda apenas de forma esporádica, acidental. (MARX, 2013, p. 430).

Como não poderia ser diferente, Marx desenvolve esse aspecto dos modos anteriores de produção para explicitar as marcas do modo de produção do capital, ao menos aqui em sua fase manufatureira, e o progressivo aprofundamento da relação entre capital e trabalho, alterando dialeticamente a própria divisão do trabalho na sociedade; antes, o que era pressuposto é reposto sob outra forma, agora subordinada. Na sequência, e apenas em referência a esta distinção, Marx fornece indicativos da divisão social do trabalho na sociedade indiana e do baixo grau de divisão no interior da própria produção em si devido à autoridade superior que fixa como lei inquebrantável determinado planejamento de tal divisão. Em termos conclusivos, escreveu Marx:

O organismo produtivo simples dessas comunidades autossuficientes, que se reproduzem constantemente da mesma forma e, sendo ocasionalmente destruídas, voltam a ser construídas no mesmo lugar, com os mesmos nomes, fornece a chave para o segredo da imutabilidade das sociedades asiáticas, que contrasta de forma tão acentuada com a contínua dissolução e reconstrução dos Estados asiáticos e com as incessantes mudanças dinásticas. A estrutura dos elementos econômicos fundamentais da sociedade permanece intocada pelas tormentas que agitam o céu da política. (MARX, 2013, p. 431-2).

Façamos o mesmo tipo de questionamento de antes: guardadas as variações concretas da esfera política, isto é, mais despótica ou mais democrática, e também tendo em mente o caráter ativo desta esfera, se o processo de dissolução e reconstrução dos Estados asiáticos não altera os elementos econômicos fundamentais, como poderia ser, na materialidade mesma, a existência da sociedade explicada por sua formação de Estado? Que validade objetiva teria o aforismo especulativo que põe o Estado como aquilo que gera a sociedade? Por estes termos, somados aos anteriores, ficam patentes tanto o distanciamento de Tragtenberg no que tange à determinação fundamental marxiana das relações e condições materiais como anterioridade ontológica da formação de Estado, quanto sua inclinação para o aforismo hegeliano. Tragtenberg não apenas está distante como também conclui pela inversão dos nexos reais em favor de um aforismo idealista que, como vimos pelas palavras de Marx, não parte dos homens reais e volatiliza-se num misticismo lógico, panteísta. Revelamos que Hegel ocupa um lugar nessa problemática de Burocracia e ideologia muito mais importante do que se supõe. E tudo indica que a solução especulativa tragtenbergianamente adaptada é resultado do amálgama problemático, sobretudo na aproximação exagerada entre Marx e Hegel.

Podemos observar que em Marx e, igualmente, do ponto de vista da efetividade, é difícil sustentar uma autêntica cisão entre a vida política e material no modo de produção asiático. Mais difícil ainda é dar provas que, de fato, fora o Estado o causador primário da sociedade nesse mesmo modo de produção. Por tudo isso é possível avaliar que Tragtenberg realiza em Burocracia e ideologia uma problemática recuperação de Marx (e também de Hegel) no que tange ao modo de produção em questão, desconsiderando a função da entrada de uma análise dos modos pré-burgueses para a determinação da diferença específica da produção capitalista. O resultado não é outro senão um apelo ao problemático regresso de Marx a Hegel, de uma continuidade Hegel-Marx, favorecendo o místico aforismo especulativo ao invés de partir dos homens e dos seus nexos reais, da processualidade real historicamente contraditória.

Em virtude dos motivos que expusemos, não é sustentável a afirmação de uma "continuidade Hegel-Marx" senão como uma continuidade sem Marx. A relação entre os autores alemães é decisivamente mais complexa, de crítica e superação, de retenção e transformação radical constituindo um pensamento 
propriamente marxiano. Nesse sentido, Marx não pode ser descrito como herdeiro dos esquemas explicativos hegelianos para a compreensão da burocracia como classe dominante nem como herdeiro do método dialético sem as problemáticas envolvidas nessas afirmações. E é o amálgama entre Hegel e Marx que cria as condições para que Tragtenberg recorra ao aforismo especulativo ao apreciar o modo de produção asiático, argumentando por uma cisão autêntica entre Estado e sociedade no modo de produção asiático. A avaliação termina por identificar, de um lado, as fortes relações de reciprocidade e o papel central do Estado nessa sociabilidade passada (e suas variações), com, de outro lado, a relação de pressuposição ontológica. Onde quer que as funções do Estado nesse modo de produção em particular apareçam como centrais, Tragtenberg especulativamente as identifica como causadoras primárias da sociabilidade quando, ao contrário e materialmente falando, são as circunstâncias concretas das relações sociais que criam as condições para a formação política e para a reciprocidade que depois opera de modos bastante distintos e com diferentes resultados. Por isso, é possível dizer que a formação política é um resultado contingente e histórico de circunstâncias sociais determinadas e não a causação primária de qualquer sociabilidade.

\section{Considerações finais}

O tom crítico que aparece em nossas considerações não deve ser interpretado como recusa. Ao contrário, somente gastamos páginas com os autores que provocaram profundos efeitos na elaboração teórica e na práxis imediata. Este é o caso de Tragtenberg particularmente em relação à Administração enquanto área de estudos. Contra a hegemônica e mistificadora teorização, Tragtenberg traz para o primeiro plano os aspectos objetivos da dominação burocrática e como a formação teórica da administração serve à reprodução dessa relação, seja na política, na economia, na educação etc. Por esses e outros motivos, nem de longe esgotamos as problemáticas enfrentadas pelo autor e estamos muito distantes de abarcar toda a sua produção. Mas este reconhecimento não deve se cristalizar numa avaliação puramente descritiva que obstrui a apreensão de algumas problemáticas internas à própria elaboração de Tragtenberg, na medida em que as investigações realizadas pelo autor brasileiro e registradas em 1974 dão mostras de uma compreensão ainda em desenvolvimento sobre os lineamentos de Marx, sobretudo se compararmos com os textos da década de 1980 (TRAGTENBERG, 1983; 1986; 1988).

Nesse espírito, o que encontramos no capítulo que foi objeto de nossa exposição configura, em síntese, uma aplicação não simplória do silogismo hegeliano (Estado-burocracia-sociedade) transposto ao modo de produção asiático. A confusão entre o papel do Estado nesse modo de produção e a relação de pressuposição ontológica levaram Tragtenberg a uma inversão dos nexos objetivos que Marx soube tão bem reproduzir no plano do pensamento, e, assim, a estabelecer o Estado como aquilo que gera a sociedade. Foi exatamente o afastamento das considerações marxianas, incluindo a não apreensão do lugar da produção pré-capitalista na análise do capitalismo, e o amálgama entre Marx e Hegel (ainda Weber tem aqui alguma influência) que permitiram uma solução especulativa para o problema enfrentado. Ao retomarmos as considerações marxianas (e hegelianas até certo ponto), foi possível determinar que não apenas a cisão entre Estado e sociedade é um produto do modo de produção capitalista como também que apenas no plano lógico-abstrato se pode afirmar a causação primária da sociedade como sendo a formação de Estado - apenas sob a égide da filosofia especulativa esse aforismo poderia ser plenamente aceito. Mas não é o Estado que gera a sociedade; muito antes, tem nela seus pressupostos reais, as relações reais entre os homens, atua também sobre elas com variados efeitos a depender das circunstâncias históricas.

A lógica na representação de Tragtenberg como uma espécie de derivação especulativa centrada em Hegel é, nessa direção, bastante problemática e desloca a análise para um aceite relativo daquele "invólucro místico". Como vimos antes, podemos capturar que Tragtenberg estabelece com base em Hegel, mas imputando a Marx, o Estado como burocracia e esta como classe dominante. Seguindo a análise da letra de Tragtenberg, a burocracia se apresenta como classe e, ao mesmo tempo, instrumento de legitimação de si mesma. Na qualidade de Estado, ela medeia a relação de si para com a sociedade, de modo que a burocracia é, ao mesmo 
tempo, polo extremo e termo médio - um enigma difícil de resolver (como um polo pode mediar a si mesmo na relação com o polo oposto?). Desse ponto de vista, a burocracia é o Estado que gera a sociedade, é também classe dominante, é igualmente meio de legitimação de si mesma e ainda medeia sua própria relação com a sociedade. Tudo isso parece ser efeito da mistificação (obviamente não deliberada) da burocracia lançada na história como demiurgo, como poder social dominante, bem ao sabor de um Weber, bastante próxima à apreensão idealista do Estado moderno em Hegel e com pouca concatenação com a elaboração marxiana. Por isso, é possível aludir à existência de um resgate problemático de Marx num amálgama com Hegel, que terminou com a solução especulativa de determinar o Estado como o demiurgo da sociedade, uma posição bastante distante à de Marx, ainda que este também tenha sido um dos pontos de partida do autor brasileiro, isto é, aquilo que este denominou por nível lógico-histórico. Disso resulta que Hegel e o nível lógico têm um peso consideravelmente maior em Burocracia e ideologia do que frequentemente se supõe; algo que, por princípio, não torna Tragtenberg um autêntico hegeliano.

Nessa direção, nossa exposição sugere ao menos três contribuições importantes para a tradição crítica brasileira na Administração e nos Estudos Organizacionais, em particular. A primeira não é outra coisa senão o desenvolvimento da pesquisa que amplia a compreensão (não sem limites) da elaboração de Tragtenberg. Estudos dedicados aos autores brasileiros ajudam a consolidar o pensamento social que sempre nutriu uma posição profundamente crítica e igualmente dificultada nos territórios universitários do ensino em Administração. Os estudos dos problemas internos ao pensamento de Tragtenberg fazem parte de uma agenda maior de fazer avançar o pensamento social brasileiro e torná-lo parte constitutiva da formação universitária em Administração.

A segunda contribuição refere-se à indicação da existência de certo deslocamento não intencionado por Tragtenberg. Há uma forte tendência em centralizar a análise na burocracia, seja estatal ou econômica, e retirar de cena o problema do capital. Burocracia e ideologia não é um material amplamente conhecido por sua crítica ao capital senão à burocracia como forma histórica de dominação. A burocracia e o Estado aparecem tendencialmente como o efetivo poder social no lugar do capital. Em última instância, porém, uma supervalorização do Estado (e da burocracia) como demiurgo, por exemplo, pode (apenas como possibilidade) implicar uma avaliação mediata feita por leitores munidos dos mais diversos interesses que não vai além da esfera política, deixando intactas as relações materiais cuja transformação é condição para uma autêntica emancipação humana. É temeroso que as análises de Tragtenberg possam ser tomadas sob uma consciência que fixa a própria política como o horizonte da luta social. $\mathrm{O}$ autor brasileiro não intencionava isto certamente, e nada é mais refratário ao espírito libertário cultivado por Tragtenberg como comprova a leitura de outros materiais (e.g. TRAGTENBERG, 1986; 1988; 2009b). Mas Burocracia e ideologia dá ensejo do contrário por conta das próprias inclinações hegelianas ali contidas e que preponderam no interior do amálgama com Marx, fazendo do Estado (e de sua burocracia) a força social preponderante em lugar das relações materiais que são pressupostos da forma política.

Por decorrência disso, e em terceiro lugar, uma apreensão correta desses problemas requer a colocação adequada dos autênticos nexos determinativos, radicalizando aquele nível lógico-histórico, agora despido do invólucro lógico-místico, ao resguardar o cerne racional: o Estado moderno, assim como sua burocracia, explicam-se pelas relações materiais que são seu fundamento. Mesmo a própria Administração, como um conjunto teórico-técnico e como prática social específica, sobretudo na dimensão econômica, tem por pressuposto relações materiais determinadas, especificamente o modo central de produção e apropriação da riqueza socialmente constituída. Em outras palavras, a relações de propriedade seguem condicionando a forma política, bem como as teorias e práticas administrativas materializadas nas burocracias. Desse modo, é importante evitar a todo custo as mistificações decorrentes das conjunções analíticas pelo risco sempre presente do desvirtuamento da compreensão mais precisa das relações objetivas em jogo. O exemplo dado pelo efeito do amálgama entre Marx e Hegel é sinal para uma maior exigência de rigor na análise. E esta, por sua vez, não deve perder de vista os traços decisivos das relações materiais ao fundo das formas aparentes.

Existem muitas outras questões importantes a serem investigadas na elaboração de Tragtenberg. O próprio movimento intelectual do autor da década de 1960, profundamente influenciado por Hegel, pelo 
existencialismo, por Weber, cede lugar a análises históricas mais centradas em Marx nos textos do final da década de 1980. Trata-se de ampliar a investigação sobre essas questões, que neste trabalho ficou muito limitada aos problemas trazidos pelo amálgama entre Marx e Hegel e pelo problema do modo de produção asiático, que, não obstante, foi necessário enfrentar.

\section{Referências}

ACCIOLY e SILVA, D; MARRACH, S. A. (Orgs.). Maurício Tragtenberg: uma vida para as ciências humanas. São Paulo: Unesp, 2001.

ANDERSON, K. Marx at the margins: on nationalism, ethnicity, and non-western societies. Chicago: University of Chicago Press, 2010.

ANTUNES, J. Marx e o último Engels: o modo de produção asiático. 2003. Dissertação (Mestrado) - Unicamp, 2003.

ANTUNES, R. Maurício Tragtenberg: a perda de um intelectual herético. In: ACCIOLY e SILVA, D; MARRACH, S. A. (Orgs.). Maurício Tragtenberg: uma vida para as ciências humanas. São Paulo: Unesp, 2001.

BANAJI, J. Theory as history: essays on modes of production and exploitation. Leiden: Brill, 2010.

BRUNO, L. E. N. B.; ACCIOLY e SILVA, D. Maurício Tragtenberg: a ousadia de conhecer. Educação, São Paulo, v. 1, p. 68-77, 2011.

CHASIN, J. Marx - Estatuto ontológico e resolução metodológica. São Paulo: Boitempo, 2009.

DUNN, S. P. The fall and rise of the Asiatic mode of production. New York: Routledge, 2011.

FERNANDES, R. C. (Ed.). Dilemas do socialismo: a controvérsia entre Marx, Engels e os Populistas Russos. Rio de Janeiro: Paz e Terra, 1982.

GODELIER, M. Sobre el modo de production asiatico. Barcelona: Ediciones Martínez Roca, 1972.

HEGEL, G. W. F. Filosofia do direito. São Leopoldo: Unisinos, 2010.

KRADER, L. (Ed.). The Ethnological notebooks of Karl Marx. Assen: Van Gorcum, 1974.

LENIN, V. I. Cadernos sobre a dialética de Hegel. Rio de Janeiro: UFRJ, 2011.

LUKÁCS, G. Introdução a uma estética marxista. Rio de Janeiro: Civilização Brasileira, 1978.

LUKÁCS, G. História e consciência de classe. São Paulo: Martins Fontes, 2003.

MARX, K. Das Kapital. Werke, Band 25, Dritter Band, Berlin: Dietz Verlag, 1962.

MARX, K. Prefácio de "Para a crítica da economia política". In: MANUSCRITOS ECONÔMICO-FILOSÓFICOS E OUTROS TEXTOS ESCOLHIDOS. Coleção Os Pensadores. São Paulo: Abril Cultural, 1974.

MARX, K. The British rule in India. Collected Works. v. 12. Lawrence \& Wishart, 1979.

MARX, K. Teorias da mais-valia: história do pensamento econômico. v. 3. São Paulo: Difel, 1980-1985.

MARX, K. Grundrisse der Kritik der politischen Ökonomie. Werke, Band 42, Dritter Band, Berlin: Dietz Verlag, 1983a.

MARX, K. Letter 1968, Marx to Engels. Collected Works. v. 39. Lawrence \& Wishart, 1983 b. 
MARX, K. A miséria da filosofia. São Paulo: Global, 1985.

MARX, K. A sagrada família. São Paulo: Boitempo, 2003.

MARX, K. Crítica da filosofia do direito de Hegel. São Paulo: Boitempo, 2005.

MARX, K. Sobre a questão judaica. São Paulo: Boitempo, 2010.

MARX, K. Grundrisse. São Paulo: Boitempo, 2011a.

MARX, K. 18 Brumário de Luís Bonaparte. São Paulo: Boitempo, 2011 b.

MARX, K. A guerra civil na França. São Paulo: Boitempo, 2011c.

MARX, K. O Capital. v. 1. São Paulo: Boitempo, 2013.

MARX, K.; ENGELS, F. Lutas de classes na Rússia. São Paulo: Boitempo, 2013.

MENEGHETTI, F. K. Trabalho e educação em Maurício Tragtenberg. Tese (Doutorado) - Curso de Pós-Graduação em Educação. Universidade Federal do Paraná, 2009.

MENEGHETTI, F. K.; FARIA, J. H. de. Burocracia como organização, poder e controle. Revista de Administração de Empresas, v. 51, n. 5, p. 424-439, set./out. 2011.

PAÇO-CUNHA, E. (Auto)Crítica do marxismo weberiano: de Lukács a Mészáros. Verinotio, v. 8, n. 13, p. 57-67, 2012.

PAÇO-CUNHA, E. Ante a sombra de Marx: silogismo hegeliano em Burocracia e Ideologia. Revista Espaço Acadêmico, v. 13, n. 150, p. 26-38, 2013.

PAES DE PAULA, A. Tragtenberg revisitado: as inexoráveis harmonias administrativas e a burocracia flexível. Rev. Adm. Pública, Rio de Janeiro, v. 36, n. 1, p. 127-44, jan./fev. 2002.

PAES DE PAULA, A. Maurício Tragtenberg: contribuições de um marxista anarquizante para os estudos organizacionais críticos. Rev. Adm. Pública, Rio de Janeiro, v. 42, n. 5, p. 949-68, set./out. 2008.

PAES DE PAULA, A. et al. A tradição e a autonomia dos Estudos Organizacionais Críticos no Brasil. Revista de Administração de Empresas, v. 50, n. 1, p. 10-23, 2010.

SAWER, M. Marxism and the question of the asiatic mode of production. Martinus Nijhoff, 1977.

SILVA, A. O. Maurício Tragtenberg e a pedagogia libertária. Tese (Doutorado). USP, 2004.

SHANIN, T. (Ed.). Late Marx and the Russian road: Marx and 'the peripheries of capitalism'. Monthly Review Press, 1983.

TRAGTENGERG, M. Planificação: desafio do século XX. São Paulo: Senzala, 1967.

TRAGTENGERG, M. Burocracia e ideologia. São Paulo: Ática, 1974.

TRAGTENGERG, M. Uma leitura libertária de Marx. In: O CENTENÁRIO DA MORTE DE KARL MARX. Cadernos Apropuc, v. I, n. I, ago. 1983.

TRAGTENGERG, M. Reflexões sobre o socialismo. São Paulo: Editora Moderna, 1986.

TRAGTENGERG, M. A revolução russa. São Paulo: Atual, 1988. 
TRAGTENBERG, M. Memórias de um autodidata no Brasil. São Paulo: Escuta, 1999.

TRAgtengerg, M. Traços comuns. Folha de São Paulo, 27/01/1990. In: TRAGTENGERG, M. A falência da política. São Paulo: Unesp, 2009a.

TRAGTEngerG, M. A falência da política. São Paulo: Unesp, 2009 b.

TREADGOLD, D. Q. Soviet historians' views of the 'asiatic mode of production'. Acta Slavica Iaponica, n. 5, p. 1-20, 1987.

VALVERDE, A. J. R. (Org.). Maurício Tragtenberg: 10 de encantamento. São Paulo: EDUC: FAPESP, 2011.

WEBER, M. Economia e sociedade. v. 1. Brasília: Editora da UNB, 2009.

WITTFOGEL, K. A. Oriental despotism: a comparative study of total power. Yale: Yale University Press, 1963.

WOLKMER, A. C. Ideologia, estado e direito. 3. ed. São Paulo: Editora Revista dos Tribunais, 2003. 